\title{
Risk Factors, Biomarkers, Etiologic Subtypes, Outcome and Prognosis of Posterior Circulation Ischemic Strokes
}

\author{
Posterior Dolașım İskemik Inmelerinin Risk Faktörleri, Biyobelirteçleri, Etyolojik Alt Tipleri, Sonlanımları ve Prognozları
}

\author{
Mine Hayriye Sorgun, Seyda Erdoğan, Müge Kuzu, İnci Șule Gül, Hafize Çotur, Çağrı Ulukan, \\ Sefer Rızayev, Volkan Yılmaz, Sabiha Tezcan, Anwar Rawandi, Canan Togay Ișıkay
}

Department of Neurology, Ankara University School of Medicine, ibni Sina Hospital, Samanpazarı, Ankara Turkey.
Introduction: Acute infarcts in posterior circulation (AIPC) have been reported $16-39.8 \%$ of ischemic stroke patients in previous studies. The most frequent cause of AIPC was embolism from cardio-aortic, vertebra-basilar atherosclerosis or dissection, followed by large-artery atherosclerosis (LAA), small vessel disease and other causes. The aim of this study was to determine the etiologic subtypes of AIPC in our stroke registry.

Methods: We reviewed the charts of 554 patients who were admitted with acute ischemic stroke between the dates January 2011 and August 2014. The demographic data, the National Institutes of Health Stroke Scale (NIHSS) scores at admission and detailed investigations to determine etiologic focus of stroke were recorded. We determined etiologic stroke subtypes using the automated Causative Classification System (CCS). The modified Rankin Scale (mRS) scores were recorded in follow-up period.

Results: A total of $184(40.6 \%)$ patients with AIPC ( 89 females [48.4\%] and 95 males [51.6\%]; mean age, $70.6 \pm 12.5$ [25-92] years) and $268(59.3 \%$ ) patients with acute infarcts in anterior circulation (AIAC) (133 females [49.6\%] and 135 males [50.4\%]; mean age, 69.3 \pm 13.7 [28-103] years) were included in the study. History of diabetes and previous stroke were significantly more common in patients with AIPC compared to the patients with AIAC ( $p=0.04, p=0.009)$. The mean admission NIHSS score was $6.4 \pm 4.6(0-26)$ in patients with AIPC (Group 1) and 6.7 $\pm 4.3(0-23)$ in patients with AIAC (Group 2) ( $p=0.96)$. cardio-aortic embolism was more common in Group 2 compared to Group 1, but not significant $(p=0.12)$. There was no significant difference in the mean $C$-reactive protein (CRP) level between two groups $(p=0.23)$. Mortality in hospital was $14.7 \%(n=27)$ in Group 1 and $8.6 \%(n=23)$ in group $2(p=0.04)$. The median mRS was $3(0-6)$ in patients with AIPC and $2(0-6)$ in patients with AIAC during follow up period $(p=0.79)$. Recurrent stroke occurred in $1(0.5 \%)$ patient with AIPC and $8(3 \%)$ patients with AIAC $(\mathrm{p}=0.07)$.

Conclusion: AIPC was found in $40.6 \%$ of patients with acute ischemic stroke in this registry. Cardio-aortic embolism was the most common cause of AIPC group. Diabetes and previous stroke history appear to be the major risk factors for AIPC. Mortality in hospital was significantly higher in AIPC group.

Key Words: Acute Infarcts in Posterior Circulation, Risk Factors, Etiologic Subtypes, Outcome, Prognosis

Giriș: Önceki çalıșmalarda posterior dolașımda akut infarktların (PDAi) iskemik inmeli hastaların \%16-39.8'inde görüldüğü bildirilmiștir. PDAi'ın en sık sebepleri kardiyo-aortik sistemden embolism, vertebrobaziler ateroskleroz ve diseksiyondur. Bunları büyük arter aterosklerozu (BAA), küçük damar hastalı̆ı̆ ve diğer nedenler takip etmektedir. Bu çalıșmanın amacı, inme ünitemizde görülen PDAi'ların etyolojik alt tiplerinin belirlenmesidir.

Yöntem: Bu çalıșmada Ocak 2011 ve Ağustos 2014 tarihleri arasında akut iskemik inme nedeni ile hastanemize bașvurmus 554 hastanın dosyası incelenmiștir. Hastaların demografik özellikleri, bașvuru sırasındaki Ulusal İnme Sağlık Ölçeği (NIHSS) skorları, inme etyolojisine yönelik yapılmıs olan ayrıntılı tetkikleri kaydedilmiștir. İnme alt tipleri, otomatize Causative Classification System (CCS) kullanılarak belirlenmiștir. İzlem sürecindeki modifiye Rankin Ölçeği (mRS) skorları kaydedilmiștir.

Sonuclar: Calısmaya 184 (\%40.6) PDAi'ı olan hasta (89 kadın [\%48.4] ve 95 erkek [\%51.6]; ortalama yas, $70.6 \pm 12.5$ [2592] yıl) ve 268 (\%59.3) anterior dolașımda akut infarktı (ADAi) olan hasta (133 kadın [\%49.6] ve 135 erkek [\%50.4]; ortalama yaș, 69.3 13.7 [28-103] yıl) çalıșmaya dahil edildi. Diyabet ve geçirilmiș inme öyküsü PDAi'ı olan hastalarda, ADAi'ı olan hastalarla karșılaștıııldığında anlamlı olarak daha sık idi ( $p=0.04, p=0.009)$. Bașvuru sırasındaki ortalama

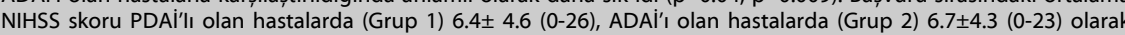
saptandı ( $p=0.96$ ). Kardiyo-aortik embolizm Grup 2'de Grup 1'e kıyasla daha sık idi ama anlamlı değildi $(p=0.12)$. Ortalama C-reaktif protein (CRP) düzeyi açısından iki grup arasında istatiksel olarak fark bulunmamaktaydı $(\mathrm{p}=0.23)$. Hastanede mortalite Grup 1'de \% $14.7(n=27)$ Grup 2'de ise \% $8.6(n=23)$ idi $(p=0.04)$. Izlem sürecinde PDAi'ı olan hastalarda ortalama mRS skoru $3(0-6)$ iken ADAi'ı olan hastalarda $2(0-6)$ idi $(p=0.79)$. Rekürren inme PDAi'ı olan hastaların 1 'inde (\%0.5), ADAi'ı olan hastaların 8'inde (\%3) saptandı $(\mathrm{p}=0.07)$

Sonuç: İnme ünitemizde takip edilen akut iskemik inmeli hastaların \%40.6'sında PDAi saptanmıștır. PDAi'ı olan hastalarda en sık neden kardiyo-aortik embolizm idi. Diyabet ve geçirilmiș inme öyküsü PDAi için majör risk faktörleri olarak saptandı. Hastanede mortalite PDAi grubunda anlamlı olarak daha yüksek idi.

Anahtar sözcükler: Posterior Dolașımda Akut Infarct, Risk Faktörleri, Etyolojik Alt Tipleri, Sonlanım, Prognoz 
Acute infarcts in posterior circulation (AIPC) have been reported 16-39.8\% in previous studies $(1,3,5-7,9,10)$. The most frequent cause of AIPC was embolism from cardio-aortic, vertebra-basilar atherosclerosis or dissection, followed by large-artery atherosclerosis (LAA), small vessel disease and other causes.

The aim of this study was to determine the prevalence, etiologic subtypes, stroke severity and prognosis of patients with AIPC compared to acute infarcts in anterior circulation (AIAC) in our stroke registry.

\section{Methods}

The medical records of 554 consecutive patients who were admitted with acute ischemic stroke from January 2011 to November 2014 were retrospectively evaluated. Approval was obtained from the research ethic committee in advance of the study. Posterior circulation ischemic stroke (PCS) was defined as acute infarcts in isolated posterior circulations (Figure 1). The patients with PCS were selected based on diffusion weighted imaging (DWI). The patients were divided into two groups; group 1 included patients with AIPC and group 2 included patients with AIAC. The patients with acute multiple ischemic lesions located in anterior and posterior circulations and without performed DWI were excluded.

Patient demographics and medical risk factors, including history of hypertension, diabetes, hyperlipidemia, atrial fibrillation, congestive heart failure, coronary artery disease, previous transient ischemic attack, previous stroke, the National Institutes of Health Stroke Scale (NIHSS) scores at admission and C-reactive protein (CRP) level at admission were collected using a standard data collection form and entered into an institutional database. Hypertension was defined as blood pressure $>=140 / 90 \mathrm{mmHg}$ on repeated measurements or prior use of antihypertensive medication, diabetes mellitus (DM) as fasting blood glucose level $>=126 \mathrm{mg} / \mathrm{dL}$ on repeated measurements or the use of medications to lower blood glucose, atrial fibrillation by previous history or if detected on ECG or Holter. Coronary artery disease included any history of angina, myocardial infarction or coronary revascularization.

A single rater (MHS) determined etiologic stroke subtypes using the automated Causative Classification System (CCS, available at https://ccs.mgh.harvard.edu) (11). The CCS subtypes included supra aortic large artery atherosclerosis, cardio-aortic embolism, small artery occlusion, other causes and undetermined causes. Etiologic workup included vascular imaging studies, such as carotid Doppler ultrasonography, computerized tomography angiography, magnetic resonance angiography or digital subtraction angiography, transthoracic or transesophageal echocardiogram, 24-hour cardiac rhythm monitoring, and laboratory tests for hypercoagulability and vasculitis. The modified Rankin Scale (mRS) scores were recorded according to follow-up visits of the patients.

Statistical analysis was performed using the Statistical Package for the Social Sciences (SPSS) 16.0 version (SPSS Inc. Chicago, Illinois, USA). Descriptive statistics were expressed as means/standard deviations for normally-distributed continuous variables and median/interquartile range for non-normally distributed variables. Statistical analysis was performed to determine the prevalence and prognosis of the patients with AIPC and AIAS. The group rates were compared using a chi-squared test, and the means were compared using Student's t test; $\mathrm{p}<0.05$ was considered to be statistically significant.

\section{Results}

A total of $184(40.6 \%)$ patients with AIPC (89 females [48.4\%] and 95 males [51.6\%]; mean age, $70.6 \pm 12.5$ [25-92] years) and 268 (59.3\%) patients with AIAC (133 females [49.6\%] and 135 males [50.4\%]; mean age, 69.3 \pm 13.7 [28-103] years) were included in the study. Patient demographics and vascular risk factors, including history of hypertension $\quad(\mathrm{n}=311, \quad 68.8 \%)$, diabetes $\quad(\mathrm{n}=129, \quad 28.5 \%)$, hyperlipidemia ( $\mathrm{n}=104,23 \%)$, atrial fibrillation ( $n=97,21.5 \%)$, congestive heart failure ( $\mathrm{n}=56,12.4 \%)$, coronary artery disease $(\mathrm{n}=111,24.6 \%)$, previous transient ischemic attack $(\mathrm{n}=24,5.3 \%)$ and previous stroke $(\mathrm{n}=78,17.3 \%)$ are shown in Table 1.

History of hypertension, hyperlipidemia, $\mathrm{AF}$, congestive heart failure, coronary artery disease or previous transient ischemic attack was not different between Group 1 and Group 2 $(\mathrm{p}>0.05)$. However, history of diabetes and previous stroke were significantly more common in the patients with AIPC compared to the patients with AIAC $(\mathrm{p}=0.04$, $\mathrm{p}=0.009)$ (Table 1).

The mean admission NIHSS score was $6.4 \pm 4.6(0-26)$ in the patients with AIPC and $6.7 \pm 4.3(0-23)$ in the patients with AIAC $(\mathrm{p}=0.96)$ (Table 1). The mean CRP level was $21.15 \pm 36.4 \mathrm{mg} / \mathrm{dl}$ in Group 1 and $24.71 \pm 39.6 \mathrm{mg} / \mathrm{dl}$ in Group 2 at admission $(\mathrm{p}=0.23)$.

The etiologic stroke subtypes in Group 1 were large-artery atherosclerosis (LAA) in $52(28.3 \%)$ patients, cardioaortic embolism in $73(39.7 \%)$ patients, small artery occlusion in 12 $(6.5 \%)$ patients, other causes in nine $(4.9 \%)$ patients and undetermined causes in $38(20.7 \%)$ patients. The etiologic stroke subtypes in Group 2 were large-artery atherosclerosis (LAA) in $62(23.1 \%)$ patients, cardioaortic embolism in 124 (46.3\%) patients, small artery occlusion in 12 $(4.5 \%)$ patients, other causes in 15 $(5.6 \%)$ patients and undetermined 
causes in $55(20.5 \%)$ patients. Cardioaortic embolism was more common in Group 2 compared to Group 1, but not significant $(p=0.12)$ (Table 2$)$.

Mortality in hospital was $14.7 \%(n=27)$ in Group 1 and $8.6 \% \quad(n=23)$ in group 2. It was significantly higher in Group 1 compared to Group 2 ( $\mathrm{p}=$
0.04). The follow-up information was accessible for 308 patients. The median follow-up time was nine (132) months. The median mRS score was $3(0-6)$ in patients with AIPC and $2(0-6)$ in patients with AIAC during this period $(p=0.79)$. Recurrent stroke occurred in one $(0.5 \%)$ patient with AIPC and in eight (3\%) patients with AIAC. There was no significant difference between the groups $(\mathrm{p}=0.07)$ (Table 1).

On logistic regression analysis, DM, previous stroke history and mortality in hospital were significantly associated with AIPC, see Table 3.

Table 1: Epidemiologic and clinical characteristics of patients with AIPC and AIAC

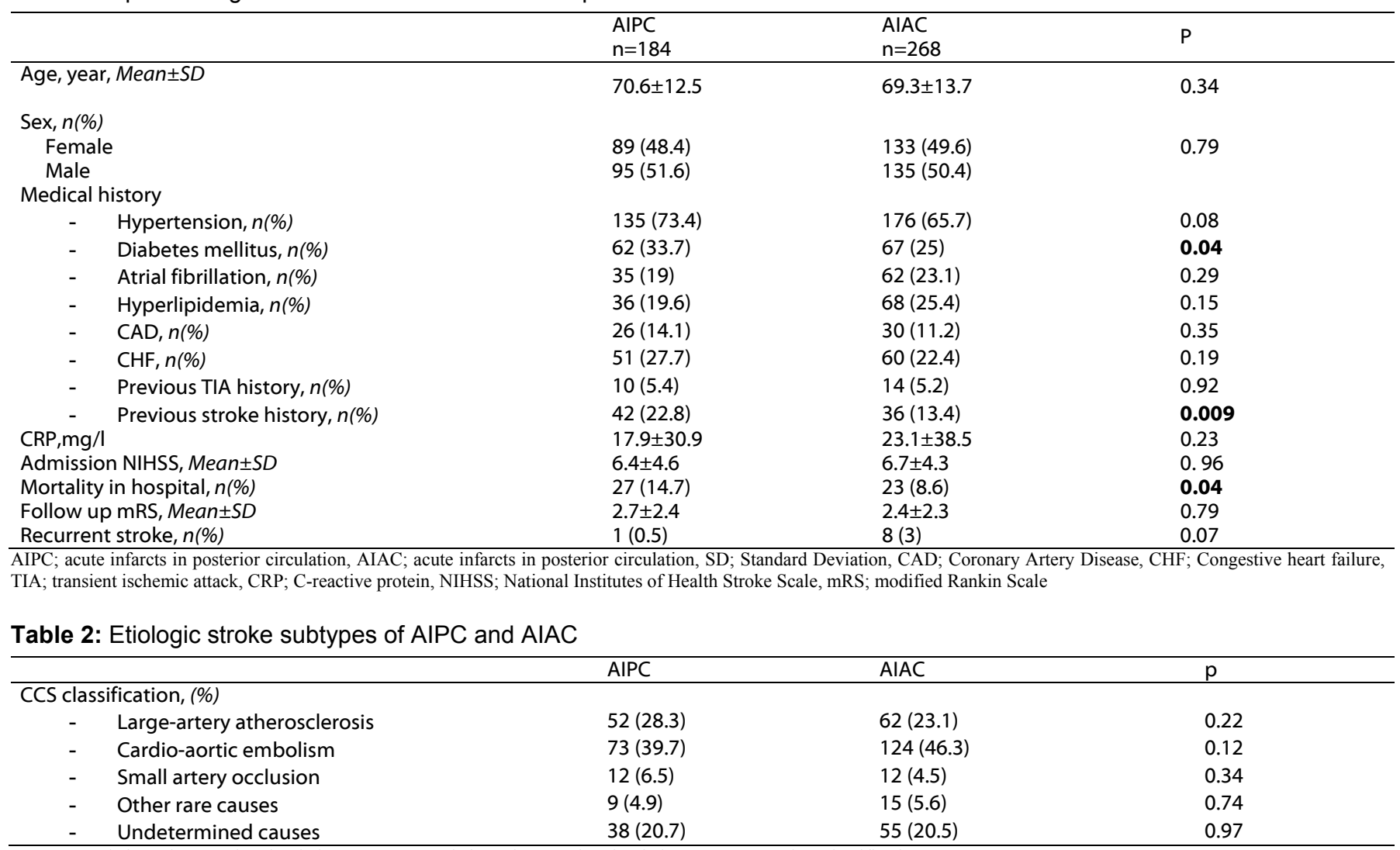

AIPC; acute infarcts in posterior circulation, AIAC; acute infarcts in posterior circulation, CCS; Causative Classification System

Table 3: Logistic regression analysis of AIPC

\begin{tabular}{llll}
\hline & OR & $95 \%$, CI & p \\
\hline DM, $n(\%)$ & 1.46 & $1.013-2.987$ & $\mathbf{0 . 0 3 7}$ \\
Previous stroke history, $n(\%)$ & 1.81 & $1.003-2.997$ & $\mathbf{0 . 0 2 2}$ \\
Mortality in hospital, $n(\%)$ & 1.66 & $1.012-2.989$ & $\mathbf{0 . 0 4 4}$ \\
\hline
\end{tabular}

\section{Discussion}

AIPC were reported 16-39.8\% of ischemic stroke patients in previous studies $(1,3,5,6,7,9,10)$. In our registry, AIPC was found in 184 $(40.6 \%)$ patients. It was higher than the other studies $(1,3,5,6,7,9,10)$.

In some of previous studies, the most common vascular risk factor was hypertension followed by smoking, DM, hyperlipidemia, cardiac disease and previous stroke history in patients with AIPC, but they did not compare with AIAC group $(7,8)$.

Miyamoto et al. found that younger age and hyperlipidemia were significantly associated with AIPC group (5). In another study by Tao et al., male gender and DM was significantly associated with AIPC (3). Otherwise, most of studies showed that AF was higher in patients with AIAC $(1,3$, 5). Conversely, Sato et al. did not find any significant difference between patients with AIPC and AIAC (6). In our study, DM and previous stroke history were significantly associated with AIPC. 
In previous studies, the most frequent stroke subtype was LAA in AIPC group $(5,6,7,8,9,10)$. Otherwise, we found that cardio-aortic embolism was the most frequent stroke subtype in patients with AIPC.

Miyamoto et al. reported that LAA was higher in AIPC group and cardioaortic embolism (CE) was higher in AIAC group (5). De Marchis et al. showed that small artery disease was significantly more frequent in patients with PCS than patients with anterior circulation ischemic stroke (1). On the other hand, Sato et al. did not find any significant difference between AIPC and AIAC group (6). There was no significant difference between two groups in our study.

Most of previous studies reported that lower NIHSS score at admission was significantly associated with AIAC group $(1,3,6,7)$. In our study, the mean admission NIHSS score was lower in patients with AIPC than patients with AIAC, but the

\section{REFERENCES}

1. De Marchis GM, Kohler A, Renz N et al. Posterior versus anterior circulation strokes: comparison of clinical, radiological and outcome characteristics. J Neurol Neurosurg Psychiatry 2011; 82:33-37.

2. Searls D, Pazdera L, Korbel E, Vysata O, Caplan LR. Symptoms and signs of posterior circulation ischemia in the New England medical center posterior circulation registry. Arch Neurol 2012;69:346-351.

3. Tao W, Liu M, Fisher $\mathrm{M}$ et al. Posterior versus anterior circulation infarction: how different are the neurological deficits? Stroke 2012;43:2060-2065.

4. Argentino C, De Michele M, Fiorelli M et al. Posterior circulation infarcts simulating anterior circulation stroke: perspective of the acute phase. Stroke 1996;27:1306-1309. difference was not statistically significant.

Sato et al. reported that the mRS scores at $3^{\text {th }}$ month were lower in patients with AIPC than in patients with AIAC (6). But, De Marchis et al. found no statistically relevant difference in outcome or mortality between patients with AIPC and AIAC (1). Lee et al. did not find any significant difference with regard to the proportion of patients with clinical improvement or clinical worsening during hospitalization and in-hospital mortality between AIPC and AIAC groups, too (7).

Mortality in hospital was significantly higher in AIPC group compared to AIAC group in our study. Otherwise, there was no significant difference in follow up mRS scores and recurrent stroke prevalence between two groups.

There are several limitations of our study, including its retrospective design, unavailable data of clinical

5. Miyamoto N, Tanaka $\mathrm{Y}$, Ueno $\mathrm{Y}$, et al. Comparison of clinical backgrounds with anterior versus posterior circulation infarcts. J Stroke Cerebrovasc Dis 2010;19:393-397.

6. Sato S, Toyoda $\mathrm{K}$, Uehara $\mathrm{T}$ et al. Baseline NIH Stroke Scale Score predicting outcome in anterior and posterior circulation strokes. Neurology 2008;70:2371-2377.

7. Lee JH, Han SJ, Yun YH, Choi HC, Jung $\mathrm{S}$, et al. Posterior circulation ischemic stroke in Korean population. Eur J Neurol 2006; 13: 742-748.

8. Mehndiratta M, Pandey S, Nayak R, Alam A. Posterior circulation ischemic strokeclinical characteristics, risk factors, and subtypes in a north Indian population: a prospective study. Neurohospitalist 2012; 2: 46-50. findings and hemodynamic parameters on admission, and a relatively short follow up duration. In addition, this is a restriction of the cohort to a single medical center. However, all of our patients underwent a detailed work-up for determining causative mechanism of ischemic stroke. Acute ischemic lesions were identified with diffusion weighted imaging in all patients. In contrast to the previous studies, etiologic subtypes of AIPC have been determined systematically according to the CCS in our patients.

In conclusion, AIPC was found in 40.6\% of patients with acute ischemic stroke in this registry. Cardio-aortic embolism was the most common cause of AIPC group opposite to previous studies. DM and previous stroke history appear to be the major risk factor for AIPC. Mortality in hospital was significantly higher in AIPC group.

9. Kim SH, Lee JY, Kim do $\mathrm{H}$, et al. Factors related to the initial stroke severity of posterior circulation ischemic stroke. Cerebrovasc Dis. 2013;36:62-68.

10. Puustjärvi V, Strbian D, Tiainen M, et al. Recognition of posterior circulation stroke. Acta Neurol Scand. 2015;131:389393

11. Ay H, Furie KL, Singhal A, et al. An evidence based causative classification system for acute ischemic stroke. Ann Neurol 2005; 58: 688-697. 